\title{
THEORY AND PRACTICE OF EXPERIMENTAL LEARNING OF THE FUTURE PRESCHOOL TEACHERS IN SLOVENIA
}

\author{
Jurka Lepičnik Vodopivec
}

\begin{abstract}
In this contribution, we attempt to answer the question of how experimental learning is implemented in the educational program for future preschool teachers. At the same time, it is important to know that the ideas of experimental learning represent a consequence of searching a closer connection between theory and practice; in particular, in the processes of educating teachers/preschool teachers its beginnings date back to the era of reform pedagogy. In the first part, we will introduce the grounds of the experimental learning of preschool teachers. In the second part, we will present the findings of a survey on implementing the experimental learning in the educational program for future teachers of preschool children. We were interested in the assessment of representation of experimental learning in the undergraduate educational studies from the point-of-view of future preschool teachers, in the assessment of expected knowledge gained during the studies and in the evaluation of expected communication skills during the studies. The contribution reveals new questions about the possibilities of experimental learning of future preschool teachers; such possibilities are necessary so that the appropriate integration of experimental learning would contribute to higher professionalism of preschool teachers.
\end{abstract}

\section{Key words}

Education, experimental learning, preschool teachers.

\section{Introduction}

Ideas about experimental learning date back into the era of the school-reform movement. The representatives of this movement, John Dewey and George Kerchensteiner in particular (Gudjons, 1994), attempted to prove a connection between activity, thinking and learning. These questions are also addressed by Jean Piaget, Kurt Lewin and David Kolb, who consider the connection between them, each from his own point-of-view (Marentič- 
-Požarnik, 2000). The need for searching a closer connection between theory and practice is reflected in the formation of experimental learning. In recent decades, experimental learning has spread widely and been established in the process of educating teachers and preschool teachers, especially in learning social and communicational skills.

Drawing on the assessment that experimental learning is "a form of learning, which connects a direct experience (experiencing), observation (perception), familiarization (cognition) and handling (action) into one inseparable entity" (Marentič-Požarnik, 2000, 124), we can recognize an interlacing of knowledge, practical handlings and a personal-emotional development in it. The author believes that experimental learning is a cyclic process (here the conflicts between dialectically opposing ways of familiarization are solved), an integrated/holistic adaptation to the world (here the processes of perception, empathy, thinking and operation are being connected into an inseparable entity), and is a process of creating knowledge (because it means a constant transformation of knowledge, notions and ideas). It is also a life-long process, which, as Kolb believes (Marentič-Požarnik, 2000), starts at the time of obtaining knowledge (formal schooling), continues with a specialization of professional or expert knowledge and ends with an integration of this knowledge with wider values and social dimensions.

In addition to traditional learning methods, which include courses and working with a text, in experimental learning, by Walter and Marks (1981), in Marentič-Požarnik $(1987,200)$, the prevailing learning methods are central and supportive. Central methods of experimental learning are simulations, role-plays, structural assignments; the supportive ones are observation of process, time to think, visualization, project methods, cases studies. The author cites Klippert (1986), who categorizes experimental learning methods by the place of gaining experience. She distinguishes between (school) reality (excursions, project methods, investigating school practice, performances, developing small learning papers and other tools, a pedagogical practical training, etc.) and simulated reality, in which she places simulations, roleplays, etc.

The main goal of educating teachers is, as Marentič-Požarnik (1987) believes (beside knowing the field of expertise), theoretical proficiency in pedagogy, psychology, didactics and other sciences, knowing various methods, techniques, approaches, integration of various tools, etc., as well as training 
the teacher to take actions, which are based on a weighted knowledge, or as the author says, "thoughtful handling" If we also add theoretical competence in preschool pedagogy, as well as developmental psychology and methodologies, we can apply the goals of education to the sector of education of preschool teachers. The author believes that thoughtful handling is "the key part of professionalizing teacher's vocational study, because it is a process, which raises the teacher's level from craft to science" (Marentič-Požarnik, 1987, 86). Therefore, a good preschool teacher is the one who promptly analyses gained experiences and learns from them. This represents the condition for his/her flexibility in handling, for decision-making autonomy, for openness for thoughtful handling and creative approach in teaching. Because the preschool teacher's handling and decision-making in the school are being directed by various subjective theories and other cognitions, it is important that these theories are connected and enriched with scientific theories in the process of educating preschool teachers. This is only possible with a planned and a deliberated integration of bonding these theories into methods and organization of education for preschool teachers.

It is indisputable that future preschool teachers cannot develop their own professional knowledge until they are able to be in contact with practice and experience the dynamic, which goes on in the pedagogical process. In Europe and around the world, there are various models of educating teachers and preschool teachers; consequently, the extent and the time disposition of pedagogical practices in study programs vary as well. The practice is organized, either at the end or in the middle of a program, or is (more or less) spaced out as evenly as possible in the second half of the study. Handal and Lauvas (Cvetek, 2000) recognize that in the case of practice being carried out at the end of the program, there is (in time) a noticeable discrepancy between theory and practice. In this case, the pedagogical staff is specialized either in theory or in practice. The communication between the teachers worsens, so that the differences in status begin to increase and the practical part mostly becomes the task of external co-workers and beginners. The authors Pucett, Diffily (2004), Sarancho, Spodek (2002) understand the relationship between the theoretical and the practical part of the programs for educating teachers as dialectic and not as a question of adequate sequence and stress, that pedagogical practice should be included in the study program with a special purpose and with a goal of bridging the gap between theory 
and practice. The goals of pedagogical practice include the integration of pedagogical skills, gaining self-confidence, a competence of making contacts and getting to know students or children, learning the preschool teacher's administrative obligations, etc. For most of the students, pedagogical practice also represents a time of dramatic changes and changes of aspects about learning and teaching.

A common thread in various notions of experimental learning can be recognized by emphasizing the individual's direct, active involvement into a typical, everyday life situation, in which he/she gains direct experience or by thinking (reflection) about gained experience. Both components of experimental knowledge, together with the academic knowledge form a model, which is implemented as a reflective model of professional educating of preschool teachers (Cvetek, 2000). The author explains that from a historic point-of-view, it is possible to identify at least three models of professional educating of teachers. This is called the pre-technocratic model, or master model. Its focus is on transferring knowledge from the teacher to a student and the controlling facts as well as routine procedures are extremely important elements. The difference in the technocratic model is in the presence of a sharp boundary between academically educated experts, whose tasks are reduced mostly to exploring activities and between the users of their knowledge in the practice. The technocratic model is followed by a post-technological model of professional education, which is based on the recognition that new realizations constantly transform the existing practice. Its consequence is creating new recognitions, which affect the practice and change it. In these educational conditions, under which theory and practice support and fulfill each other, the importance of professional competence and the skill to use reflection is increasing together with a goal of achieving higher efficiency in practice.

\section{Problem of the research}

The higher educational professional program that is implemented at the Faculties of Education in Maribor, Ljubljana and Koper includes a three-year educational program and enables the acquisition of a higher professional education and a Master's degree in preschool education.

In the curriculum for an educator of preschool children, the observational/integrated practice consists of 285 hours or $12.7 \%$ of the whole cur- 
riculum. This means that the students of each class spend one day per week at preschool, where they mostly systematically observe, learn and analyze the work in the school. The goal of observational/integrated practice is familiarization with the daily work of a preschool teacher; the approximation of the work and life in the preschool, as directly as possible; getting to know children and familiarization with the practical part; partially or completely independent execution of activities under the supervision of preschool teacher/mentor. The main purpose is also an ongoing assessment, usage of gained theoretical knowledge and a reflection of events in practice. Practice hours are divided between study courses and are implemented as observational exercises, preschool teacher's exemplar performances and performances of students in the preschool. Performances of individual methodologies and seminar papers of integrated practice, which are linked to the direct preschool work, where the student learns the meaning of observational technique, technique of evaluation and documentation, have a special position.

Training students in the preschool is structured and left to the decisions of mentors, as well as with the agreement between teachers and mentors, or on the basis of an agreement between the Faculty of Education and the preschool. In such a designed program, there exists a wish for intertwining and uniting:

$>$ Knowledge, which future preschool teachers gain at basic courses, through lessons, seminars, study of literature, etc.

$>$ Practical handlings, which they gain through class inspection and performances.

$>$ Personal development, which is influenced by various forms of social learning, trainings of social skills and other.

\section{Research Focus}

Training students in the preschool is structured and left to the decisions of mentors, as well as with the agreement between teachers and mentors, or on the basis of an agreement between the Faculty of Education and the preschool. In such a designed program, there exists a wish for intertwining and uniting:

$>$ Knowledge, which future preschool teachers gain at basic courses, through lessons, seminars, study of literature, etc., 
$>$ Practical handlings, which they gain through class inspection and performances,

$>$ Personal development, which is influenced by various forms of social learning, trainings of social skills and other.

\section{Methodology of Research}

\section{General Background of Research}

The questions of implementing programs of educating future preschool teachers, which we encounter both in theory and practice, are frequently connected with the professionalism of preschool teacher's expert education.

According to this, we are interested in:

$>$ The assessment of representation of experimental learning in the high education program Preschool Pedagogy.

$>$ The assessment of the representation of experimental learning in the undergraduate education from the future preschool teachers' point-of-view.

$>$ The assessment of expected knowledge gained during studies.

$>$ The assessment of expected communicational skills during studies.

When analyzing the stated problem and searching for answers to the research questions asked, we rely on the descriptive and comparative method of non-experimental pedagogical research.

Our research is divided into two parts. In the first part, we relied on the method of analysis and synthesis. We were trying to determine if the valid programs of undergraduate education of preschool teachers in Slovenia contain experimental learning of future preschool teachers. In the second part, we first tried to determine the assessment of representation of experimental learning in the programs of undergraduate education of preschool teachers. This was done with descriptive statistics. We were also interested in the assessment of future preschool teachers and focused on which knowledge and skills they gain in the time of their study.

\section{Sample of Research}

The representative sample includes 102 students of Preschool Pedagogy at the Faculty of Education at the University of Maribor. The sample includes 36 students of the first year, 32 students of the second year and 34 students 
of the third year. The share of interviewed is fairly equal, because the students of the first year represent $35.3 \%$ of all the interviewed, the students of the third year represent $33.3 \%$ of all the interviewed and the students of the second year represent $31.4 \%$ of all the interviewed. Regarding the study year's criterion, it has been estimated that the example is balanced.

\section{Instrument and Procedures}

The research took place at the Faculty of Education, University of Maribor in 2010. The data was gathered with a quantitative technique. The questionnaire was prepared on the basis of literature connected with the research problem. After an experimental sounding (on a sample of 21 students, seven from each year), we eliminated the recorded shortcomings and checked the clarity of the instructions and adequacy of the given answers to the particular questions. This was followed by a correction of the questionnaire and its final usage on the representative example. Before the interview, the students were introduced to the purpose of the research. Afterwards, they filled out the questionnaires independently and without guidance. The time for solving was unlimited.

\section{Data analysis}

For processing the data, we used a quantitative method. In the first phase of the process, one of the questionnaires was excluded, because it was not correctly complied. The obtained data was processed with the SPSS program. The data was presented as table, together with the reference of absolute (f) and percentage ( $\mathrm{f} \%$ ) frequencies. The existence of dependent connections between variables was tested with a $\chi^{2}$-test. We used Kruskal-Wallis test of differences. 


\section{Results of Research}

Assessment of the amount of experiential learning in undergraduate study in terms of future preschool teachers

Table 1: Years of study in correlation with the assessment of experiential learning integration in pre-primary education study

\begin{tabular}{|l|c|c|c|c|c|}
\hline \multirow{2}{*}{ Experiential study } & \multicolumn{3}{|c|}{ Year of study } & \multirow{2}{*}{ Total } \\
\cline { 2 - 5 } & $1^{\text {st }}$ year & $2^{\text {nd }}$ year & $3^{\text {rd }}$ year & \\
\hline \multirow{2}{*}{ Yes } & $f$ & 13 & 5 & 10 & 28 \\
\cline { 2 - 6 } & $f \%$ & $36.1 \%$ & $15.6 \%$ & $29.4 \%$ & $27.5 \%$ \\
\hline \multirow{2}{*}{ Partly } & $f$ & 17 & 19 & 18 & 54 \\
\cline { 2 - 6 } & $f \%$ & $47.2 \%$ & $59.4 \%$ & $52.9 \%$ & $52.9 \%$ \\
\hline \multirow{2}{*}{ No } & $f$ & 5 & 8 & 6 & 19 \\
\cline { 2 - 6 } & $f \%$ & $13.9 \%$ & $25.0 \%$ & $17.6 \%$ & $18.6 \%$ \\
\hline \multirow{2}{*}{ I don't know } & $f$ & 1 & 0 & 0 & 1 \\
\cline { 2 - 6 } & $f \%$ & $2.8 \%$ & $0 \%$ & $0 \%$ & $1.0 \%$ \\
\hline \multirow{2}{*}{ Total } & $\mathrm{f}$ & 36 & 32 & 34 & 102 \\
\cline { 2 - 6 } & $\mathrm{f} \%$ & $100 \%$ & $100 \%$ & $100 \%$ & $100 \%$ \\
\hline
\end{tabular}

$$
\begin{array}{|c|}
\hline \chi^{2}=6.552 \\
g=6 \\
p=0.364
\end{array}
$$

Even though there was no statistical significance found in the student assessment of experiential learning integration in pre-primary education study $(\mathrm{P}>0.05)$, we can find that from the results seen in Table 2, a majority of all respondents $(54.0 \%)$ stated that experiential learning is partly included in pre-primary education study. Such an evaluation was made by most students from the $2^{\text {nd }}$ year $(59.4 \%)$ and slightly less by ones in the $3^{\text {rd }}$ year $(52.9 \%)$. Therefore, students are mostly not entirely satisfied with the share of experiential learning in pre-primary education study. It is estimated that their opinion is quite realistic because they have been through a year or two of their study, and therefore they had sufficient opportunity for a personal experience of experiential learning. The reasons for their decisions are certainly diverse and it would not be appropriate to speculate on them. However, we can 
understand this information as a warning that we should pay more attention to experiential learning integration in these programs when planning new undergraduate programs for preschool teachers for preschool children.

Assessment of expected knowledge and skills of communication, gained by future preschool teachers in their time of study

Table 2: The number (f) and percentage ( $\mathrm{f} \%$ ) of students' assessment of gained knowledge and skills of communication, ranked on average marks.

\begin{tabular}{|c|c|c|c|c|c|c|c|}
\hline \multicolumn{2}{|c|}{$\begin{array}{l}\text { Knowledge and skills of } \\
\text { communication }\end{array}$} & $\begin{array}{l}\text { Yes } \\
\text { (4) }\end{array}$ & $\begin{array}{l}\text { Partly } \\
\text { (3) }\end{array}$ & $\begin{array}{l}\text { No } \\
(2)\end{array}$ & $\begin{array}{l}\text { I don't } \\
\text { know } \\
(1)\end{array}$ & Tot & Average \\
\hline \multirow{2}{*}{$\begin{array}{l}\text { Pedagogical-psycho- } \\
\text { logical knowledge }\end{array}$} & $\mathrm{f}$ & & & & 0 & & \multirow{2}{*}{5196} \\
\hline & $\mathrm{f} \%$ & 9 & 820 & 90 & & 10 & \\
\hline \multirow{2}{*}{$\begin{array}{l}\text { Knowledge from indi- } \\
\text { vidual activity fields }\end{array}$} & & & & & & & \multirow{2}{*}{3.5098} \\
\hline & $\mathrm{f} \%$ & 0 & $60 .$. & & & & \\
\hline \multirow{2}{*}{$\begin{array}{l}\text { Didactical-methodical } \\
\text { knowledge }\end{array}$} & & & & & & & \multirow{2}{*}{4412} \\
\hline & $\mathrm{f} \%$ & & 53.9 & & & & \\
\hline \multirow{2}{*}{$\begin{array}{l}\text { Child communication } \\
\text { skills }\end{array}$} & $f$ & & & & & & \multirow{2}{*}{3.0686} \\
\hline & $\mathrm{f} \%$ & .0 & 40.2 & .00 & & & \\
\hline \multirow{2}{*}{$\begin{array}{l}\text { Adult communication } \\
\text { skills }\end{array}$} & $\mathrm{f}$ & & 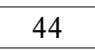 & 21 & 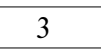 & & \multirow{2}{*}{2.8529} \\
\hline & $\mathrm{f} \%$ & $33.3 \%$ & $43.1 \%$ & $20.6 \%$ & $2.9 \%$ & $100 \%$ & \\
\hline
\end{tabular}

There are average marks evident from Table 2. According to the marks, the respondents stated that pedagogical-psychological knowledge has gotten the highest marks (3.5196), which is certainly favorable. The respondents estimate that during their studies they gain enough pedagogical-psychological knowledge needed for their future work. The marks of didactical-methodical knowledge and knowledge from activity fields have gotten quite high marks, which is favorable because it indicates that the under-graduate preschool teacher study program gives a firm and solid ground for the later professional preschool teacher development.

The mark of child communication skills (3.0686) is slightly higher than the mark of adult communication skills (2.8529). These results confirm the already-known findings that future preschool teachers are more competent in communication with children than with children's parents. The reasons 
for this might be in the pre-graduate study program, which mostly prefers working with children, whereas working with adults (especially parents) is somewhat neglected. This also shows that in the field of lifelong learning we need to pay more attention to those segments of knowledge and skills that obtained a lower average.

Statistically important differences are shown in Table 3, where we were searching for differences among individual statements according to the year of study with Kruskal-Wallis's test.

Table 3: The result of Kruskal-Wallis test of differences among statements from $\mathrm{T} 1$ to $\mathrm{T} 5$ according to the year of study

\begin{tabular}{|c|c|c|c|c|c|}
\hline Knowledge and skills & Year & $\overline{\mathbf{R}}$ & $\chi^{2}$ & g & $\mathbf{P}$ \\
\hline \multirow{3}{*}{$\begin{array}{l}\text { Pedagogical-psycho- } \\
\text { logical knowledge }\end{array}$} & First & 66.76 & \multirow{3}{*}{19.995} & \multirow{3}{*}{2} & \multirow{3}{*}{0.000} \\
\hline & Second & 45.53 & & & \\
\hline & Third & 40.96 & & & \\
\hline \multirow{3}{*}{$\begin{array}{l}\text { Knowledge from indi- } \\
\text { vidual activity fields }\end{array}$} & First & 49.18 & \multirow{3}{*}{1.189} & \multirow{3}{*}{2} & \multirow{3}{*}{0.552} \\
\hline & Second & 49.98 & & & \\
\hline & Third & 55.38 & & & \\
\hline \multirow{3}{*}{$\begin{array}{l}\text { Didactical-methodical } \\
\text { knowledge }\end{array}$} & First & 62.26 & \multirow{3}{*}{11.553} & \multirow{3}{*}{2} & \multirow{3}{*}{0.003} \\
\hline & Second & 40.92 & & & \\
\hline & Third & 50.06 & & & \\
\hline \multirow{3}{*}{$\begin{array}{l}\text { Child communication } \\
\text { skills }\end{array}$} & First & 56.08 & \multirow{3}{*}{1.629} & \multirow{3}{*}{2} & \multirow{3}{*}{0.443} \\
\hline & Second & 48.70 & & & \\
\hline & Third & 49.28 & & & \\
\hline \multirow{3}{*}{$\begin{array}{l}\text { Adult communication } \\
\text { skills }\end{array}$} & First & 51.97 & \multirow{3}{*}{0.267} & \multirow{3}{*}{2} & \multirow{3}{*}{0.875} \\
\hline & Second & 53.00 & & & \\
\hline & Third & 49.59 & & & \\
\hline
\end{tabular}

As evident from the table, there are statistically important differences according to the year of study, with regards to pedagogical-psychological and didactical-methodical knowledge. First-year students gain most of the pedagogical-psychological knowledge, followed by second- and third-year students. This is completely understandable, since most of the basic pedagogicalpsychological subjects are in the first year of undergraduate study. In terms of didactical-methodical knowledge, we can estimate that respondents in the first 
year of study find that segment more important than the ones in second and third year, even though the third-year students find it more important than second-year students do. The difference among the statements of students in different year's studies can come from the fact that first-year students are full of various, sometimes even entirely unreal expectations about their studies and their future profession. In the second year, after confronting study, these expectations slowly calm down and build up again in third year, when students are approaching the end of study and when they are preparing for their professional career.

\section{Discussion}

By analyzing the valid curricula, we came to a conclusion that the higher education study program Preschool education enables pursuit of academic ( $44.45 \%$ hours) as well as experiential ( $55.55 \%$ hours) knowledge. We can conclude that from this perspective the program is balanced. Future preschool teachers are pursuing experiential knowledge through seminar work, laboratory exercises and integrated and synoptic pedagogical practical training with performances. Integrated pedagogical practical training in the valid curricula represents 285 hours or $12.7 \%$ of all the curricula and occurs from the first to the third year's study throughout every study period, one day per week in every year's study.

Study situations are, in terms of the stated curricula, planned in such a way that they enable students to move from an abstract conceptualization, such as comprehension of concepts, regularities and theories through active experimentation and concrete experience, to a reflective observation. Lectures in which the realization of cyclic learning or Kolb's learning process begins (Marentič-Požarnik, 1987) in the 1st year's study can be continued by active experimentation and a concrete experience, which is realized by student's integrated pedagogical practical training in preschool and reflective observation, which is partly realized in preschool, where the student and mentor evaluate work and at the faculty, where students introduce their experience to other students and professors/lecturers. In this way, all four activities of Kolb's model of cyclic learning are intertwined. That is how a student can check his/her theoretical knowledge in each time in life-situations: by having knowledge of children, their specificities, their likeness and diversity, which he/she has gained at lectures, seminars, by studying literature, in professional 
dialogue etc. Experiential learning helps the student supplement and extend the theoretical knowledge he or she acquired at lectures, by studying pedagogical literature, by checking the noticed activities, reflections and feelings of children in theory. Such planned pedagogical practical training offers the student the simplest way to connect his/her acquired theoretical knowledge with practical experience as well as linking and checking the theory in practice and vice-versa, to connect practical experience and comprehension to theoretical knowledge. It is clear that the theory will be more comprehensible if it is connected with practice and that the practice will have a greater value if it is confirmed by theory.

Furthermore, the pedagogical practical training enables a student to gain practical experience. It is a pedagogical regularity by which a person learns something best when he or she is active. Students learn childcare by childcare. Therefore, they learn from their own experience, which they can gain only with their own activities. Integrated pedagogical practical training also offers a student a chance to check his/her own preparedness for work at the beginning of study. By working independently in the department, students can comprehend and check themselves, their feelings, capabilities and interests. At the same time, they can find their own skills of coordination and direction of a group of children, making contacts with children, colleagues, parents and others and by doing so, becoming aware of the fields in which more professional study will be necessary. Such a planned pedagogical practical training offers students significant learning (where students develop insight into emotional and psycho-motorical fields of their personalities, where study is connected with concrete life situations, where loose interpersonal relations prevail, and where students can search for information needed to solve a certain problem independently (Marentič-Požarnik, 1987). At this point, we are confronted with the question of how students and mentors experience the integrated pedagogical practical training, i.e. whether they experience it as a possibility to develop the stated viewpoints of a student's personality in which there are enough possibilities for learning with a concrete everyday situation or whether there are loose interpersonal relations under those conditions.

In terms of professional preschool teacher education models, we can find that we are one step forward from a technological model and almost in the post-technological model of preschool teacher education. In our opinion, 
there is still a lot of work needed to reach this level, especially in the field of closer connection among individual subjects and pedagogical training, which we understand as a possibility to gain spontaneous and planned experience in the overall time of study, and especially the experience gained during the integrated and combined training. This way, the connection between theory and practice will go in both ways and become dialectical, and the future preschool teachers will be qualified for a critical analysis and well-considered actions in practice. Practical experience gained this way serves future preschool teachers as groundwork for criticism and supplementation of already gained theoretical knowledge.

\section{Conclusions}

We have discovered that there are early methods of experiential learning appearing in the educational programs, which lose their character due to their lack of structure. We find attempts of experiential learning in current preschool education programs, although the execution of the entire cycle is questionable.

The data shows that students have mostly realistic expectations, since it is impossible for a preschool teacher to gain all the knowledge and skills needed to perform her/his professional duties in her/his time of study. Scientific and technological progress is a cause of knowledge becoming rapidly outdated, which is why education is a necessity. Students are obviously well aware of that. However, they still want the preschool teacher study program to include more experiential learning; only $27.5 \%$ of students believe that there is absolutely enough of experiential learning. The pedagogical practical training, performances, roll playing, simulations and mini-performances are methods of experiential learning, which enable students to learn through their own experience by their own actions and activities. Experiential learning is not only designed for connecting theory with practice but also for professional socialization, checking professional orientation, discovering the professional qualification for independent work, gaining self-confidence, training of pedagogical skills, making acquaintance with professional reality etc.

We used the questionnaire survey to ask students about their expectations in gaining knowledge (didactical-methodical and pedagogical-psychological knowledge and knowledge from individual activity fields) as well as child and adult communication skills. By analyzing the data, we found that students 
mostly expect that they will totally or at least partly gain knowledge and skills. According to the evaluation of gained knowledge, it is agreed that students gain enough pedagogical-psychological knowledge for their profession during their studies. Regarding adult communication, there have been slightly lower expectations stated, which might be the consequence of the preschool education program not having special subjects that focus on gaining and developing the mentioned skills. We can estimate that students will strengthen their competence in these fields during their future professional development.

In order to deal with the pedagogical practical training of future preschool teachers as an important possibility for experiential learning, we will have to reconsider the possibilities of closer connection among teachers, mentors and students in the entire process of pedagogical practical training (before, during and after its realization), because it unites the possibilities for a student's first contact with nursery school life, for checking theoretical knowledge in practice and vice-versa, for possibilities of connecting theory and practice, for experiential learning and gaining practical experience and for checking one's own qualification for working in preschool in each case.

Can we expect future preschool teachers to become reflective practitioners? The answer to this question is complex and extensive, because it is about connecting knowledge, practical questions and personality development into an inseparable integrity. In order to produce a planned and progressive awareness of future preschool teachers with the components of their existing subjective theories of teaching, learning, upbringing, relations among preschool teachers, children and parents, discovering discrepancies and illogicalities in the existing treatments and encouraging the connection of these theories with the existing objective theoretical comprehension in the existing and new education programs for future preschool teachers, we will have to dedicate more time to encourage a systematical retrieval or reconstruction of past experience and create conditions for gaining new experience at the faculty and in preschool. To this end, an even more consistent following of the realization of mutual connection of subjects as well as connecting those to pedagogical practical training as we understand it, as Marentič-Požarnik stated (1987) in a double/binary sense, i.e. as spontaneous or induced experience, gained during integrated and combined pedagogical practical training. Here it is important to preserve the connection between theory and practice, that the connection is bilateral and dialectic. In this process, the future preschool 
teacher is qualified for a critical analysis of his/her work and for a well-considered practical treatment. Practical experience serves as a foundation for development of one's own criticism towards theoretical knowledge and as a possibility for their completion.

\title{
References
}

GUDJONS, H. Pedagogija. Temeljna znanja. Zagreb: Educa, 1994.

CVETEK, S. Profesionalnost v profesijo profesorjev. In: Didaktični in metodični vidiki nadaljnega razvoja izobraževanja. Zbornik prispevkov z mednarodnega znanstvenega posveta v Mariboru, 25 in 26. novembra 1999. Maribor: Pedagoška fakulteta, Oddelek za pedagogiko, psihologijo in didaktiko, 2000, pp. 245-251.

MARENTIČ-POŽARNIK, B. Nova pota v izobraževanju učiteljev. Ljubljana: DZS, 1987.

MARENTIČ-POŽARNIK, B. Psihologija učenja in pouka. Ljubljana: DZS, 2000.

PAPOTNIK, A. in RAJTMAJER, D. In: Visokošolski strokovni program Predšolska vzgoja. Maribor: Pedagoška fakulteta, 1996.

PUCKETT, B. M., DIFFILY, D. Teaching Young Children. An Introduction to the Early Childhood Profession. $2^{\text {nd }}$ Edition. USA: Delmar Learning, 2004.

SARACHO, N. O., SPODEK, B. Studying Teachers in Early Childhood Settings. USA: Information Age Publishing, Inc., 2003.

\author{
Contact \\ Jurka Lepičnik Vodopivec \\ Ph.D., Assoc. Professor \\ Faculty of Education \\ University of Maribor \\ Maribor \\ Slovenia \\ e-mail: jurka.lepicnik@uni-mb.si
}

